Volume and Issues Obtainable at Center for Sustainability Research and Consultancy

Sustainable Business and Society in Emerging Economies

ISSN: 2708-2172 \& (E): 2708-2504

Volume 3: Issue 3 September 2021

Journal homepage: www.publishing.globalcsrc.org/sbsee

\title{
Inclusive Education Opportunities in Punjab Pakistan: A Locale Based Comparison
}

Muhammad Jahanzaib, University of the Punjab, Lahore, Pakistan

*Ghulam Fatima, University of the Punjab, Lahore, Pakistan

Dur-e-Nayab, University of the Punjab, Lahore, Pakistan

*Corresponding author's email address: fatima.dse@ pu.edu.pk

\begin{tabular}{l}
\hline ARTICLE DETAILS \\
\hline History \\
Revised format: Aug 2021 \\
Available Online: Sep 2021 \\
\hline
\end{tabular}

Keywords

Inclusive education,

Opportunities, Locale,

Differences.

JEL Classification

120, 124

P

\section{OPEN ACCESS}

ABSTRACT

Purpose: The constitution of Pakistan firmly stated that no discrimination of opportunities will be tolerated among the citizens of Pakistan on behalf of color, creed, language, disability etc. But unfortunately, the dream of equality could not become reality. Inclusive education has been taking significant importance for the education of persons with disabilities (PWD's) for a few decades. But, without equal opportunities, the seed of inclusion can never be fertiled. This study is an effort to depict the difference of existing inclusive education opportunities between rural and urban secondary schools of Punjab Pakistan.

Design/Methodology/Approach: Survey method was used to collect data from 196 male and female teachers serving in rural and urban secondary schools of conveniently selected five districts viz Okara, Lahore, Pakpattan, Sahiwal, and, kasur with a self-reporting questionnaire named Research Questionnaire on the Condition of Available Inclusive Education Opportunities in Secondary Schools of Punjab. For cross-validation, an interview schedule was made to take data from 17 students with disabilities. Both descriptive and inferential statistics were used.

Findings: The study found that there was no significant difference of inclusive education opportunities in rural and urban secondary schools of Punjab.

Implications/Originality/Value: However special students denied various opportunities claimed by the inclusive education teachers.

(C) 2021 The authors, under a Creative Commons AttributionNonCommercial- 4.0

Recommended citation: Jahanzaib, M., Fatima, G. \& Nayab, D. (2021). Inclusive Education Opportunities in Punjab Pakistan: A Locale Based Comparison. Sustainable Business and Society in Emerging Economies, 3 (3), 301-308.

\section{Introduction}

Human beings and their environment have been affecting each other since the beginning of life. Different places are not the same for living according to their circumstances. Usually, a man prefers to such places for his accommodation which can provide him better opportunities and facilities of life. That 
is why a large sect of the population is migrating from rural to urban areas. Researchers narrated that people migrated from villages to cities and towns due to large economic activities, as well as, to obtain financial benefits in the shape of better economic opportunities and rewards (Khan \& Shahnaz, 2000). Persons with disabilities have been one of the most marginalized segments of society since the start of human civilization. It is seen that the disabled residents of rural areas are usually more deprived of opportunities than handicapped residents of urban areas. In ancient times, such parents felt that they could not do anything for them. So, they considered these children a burden and a curse of God. Therefore, their physical and emotional abuses have been reported in every era. Persons with disabilities faced bigotry, injustice, and biasness in different shapes (Otieno, 2009).

Many centuries were left with such kind of unjustified and impolite behavior towards them. With the passage of time, a paradigm shift occurred when some sensitive people started to think about the communal rights of persons with disabilities. After that, many personnel took different initiatives for the rehabilitation of PWDs. Leo (1964) narrates that many of the researchers of special schooling were European doctors and most of the young, motivated persons.

Moreover, segregated special education institutions were evolved for PWDs. In that kind of institution, students with disabilities got expertise excluded from the mainstream of society. Philippe Tremblay (2007) says that Pedro Ponce de Leon (1578) in Spain formed the first institution about the instruction of hearing-impaired students.

After many experiences and observations, reserachers and humanists found many flaws in segregated school system. Then different approaches were introduced for educational rehabilitation of PWDs. Inclusive education is one of those significant approaches which acquired more attention of experts due to its effectiveness. Both defines inclusive education as a continuing course of action to enhance the involvement of learners in the culture and curricula of conventional academic institutions and communities (Booth, 1996). In simple words, inclusive education is a system where students with disabilities get educational benefits with the non-disabled peers in the same classroom of general education school with proper facilitation but without any descrimination. But at the same time, it is an undeniable reality that without some essential arrangements and opportunities inclusive education can not show its benefits. In this article, the reserchers would like to identify the situation of inclusive education opportunities in secondary schools of Punjab Pakistan. Similarly, he will try to compare the situation about the provision of inclusive education opportunities in rural and urban secondary schools.

\section{Review of the Literature}

Persons with disabilities are one of the most destitute segments of society since start of human life. They have been mistreated, cursed, and deprived by their families and society of any social and cultural activity. In ancient times, parents considered them as a burden for their home and resources. Tremblay narrates (2007) that in Greek and Roman Empire disability was considered as the curse of God. Similarly, it took as bad symbol of sin. As a result of such philosophies sometimes disabled children were left alone on the hill for death, or they were fallen from the high mountains or sometimes they were put into the prison, or they sunk into the water (Bruce, 2010; Stavrianos, et al, 2018). In the same way Rymber (2014) depicts that sometimes people accommodated the disabled persons as slaves or servants at their homes (Turner, 2014; Garland, 2020).

Furthermore, Otieno (2009) reports that Bible portrays the disability as a disease. Visual impairement, hearing impairement and speech loss are common kinds of illnesses as narrated by Bible. Most of the old testament writers believe that disability is, infact, a horrible consequence of bad deeds as well as it is a prominent sign of God's reprisal for his insubordination. In this regard, the New Testament also accepts a hidden connection between disability and sin. This kind of concepts about people having impairments made them excluded from all circles of social life (Imhoff, 2017). With the passage of time people became conscious of the rights of persons with disabilities. Some people took initiatives for their 
education. Winzer (1993) gave a list of those historical events when people took some early steps for educational rehabilitation of children with disabilities as: "Chronology of Landmark Events in the Education of the Disabled Population". In 1745, Jacob Rodrigues Perrier began his work with deaf students. In 1749, Denis Diderot published his study on blind people. In 1760, Abbe Charles Michel de I" Epee started an educational institution for deaf children in Paris. In 1784, Valentin Hauy set up a school for blind children in Paris (Esteves \& Rao, 2008). In the same way, Leo expresses that the majority of the researchers of special schooling were European doctors and most of the young motivated persons (Cretu \& Morandau, 2020).

During the $18^{\text {th }}$ and $19^{\text {th }}$ century, different educational institutions were evolved for persons with disabilities but no significant step was taken for any legislation to protect the rights of persons having impairments by any government. After a long time, in 1975, American Congress took an initiative in this regard when it approved an act for the educational rights of entire children with disabilities (CWDS). Disabled students (94-142) in community Law in 1975 named "The Education for All Handicapped Children Act". This act recommended that all students with disabilities will be given a free, suitable public education, and economic support. After a few years, this act became famous as "The individuals with Disabilities Education Act (IDEA)" (Lipki \& Okamoto, 2015).

At that time most of the special schools used to follow the segregated module in which special students obtained some educational skills in separation from the mainstream of society. But on the other side as time passes different humanistic groups raised their voice against the special education schooling system due to its segregated characteristic. Frederickson and Cline gave their opinion that the formulation of special services for segregated students with disabilities from their entire age fellows may be creating the inferiority complex, feeling of injustice, and in the end revenge from non-disabled people. As well as many questions can be raised about this system (Goransson, et al, 2020).

After such kind of criticism on segregated schooling system, various ideologies were established to fulfill the special learning needs of students with impairments without their exclusion from the mainstream. These ideologies were integration, mainstreaming, and inclusive education. UNESCO defines inclusive education as a process of addressing as well as responding to the personal learning needs of every student through enhancing involvement in education and minimizing the elimination of students with disabilities from schooling (UNESCO, 2005). Moreover, different universal declarations about human rights provide the legal foundation for inclusive education. Salamanca statement is a declaration about equal educational opportunities for persons with disabilities. In this declaration term, inclusive schooling was used first time by delegates and participants for the educational rehabilitation of children with special needs (UNESCO, 1994).

Similarly, the Dakar framework emphasizes education for all (EFA) that governments have a liability to ensure that EFA aims will be fulfilled and maintained (World Education, 2000; Shaeffer, 2002). In this regard, it is a good sign of hope that different countries provide different kinds of inclusive education opportunities to their people. Waldschmidt and Meinert (2010) express that the government of Germany provides supportive gadgets as well as arrangements to PWDS for enhancement of independence and accessibility in their daily life. German UNESCO Commission Grants awards to inclusive educational schools (Ahrbeck \& Felder, 2020). In the same way, Sweden's establishment is liable through legislation to grant several essential need base services, particularly education (Biamba, 2016).

Furthermore, Kohama depicts that the establishment of India is taking an interest to plan out strategies towards inclusive education. But on the other side, UNICEF reports that in Pakistan usually students having impairments were commonly expelled from the general education schools because school authorities and class teachers could not be able to understand the academic needs of such kinds of children (Omer, 2015; Shah, 2015).

It is seen that the situation in rural areas is worse than in urban areas. The ratio of illiteracy in villages is 
2-3 times greater than in cities. And this proportion is most influenced by opportunities of life. In the same scenario education policy 2009 elaborated some important facts and figures about the situation of Pakistan in this way in the public sector, around $40 \%$ of the schools are without boundary walls, $36 \%$ without drinking water facilities, $61 \%$ without electricity, 39\% without sanitary facilities and $6 \%$ without any buildings (UNESCO, 2017; Kapur, 2018; Shahid, 2020; Narayan \& Patnaik, 2021).

\section{Objectives of Study}

The following objectives were made to conduct the study:

1. To identify the prevailing inclusive education opportunities in secondary schools of Punjab.

2. To compare the current inclusive education opportunities of rural and urban secondary schools.

\section{Research Questions}

The study was conducted to answer the following questions:

1. What is the existing situation of inclusive education opportunities in secondary schools of Punjab Pakistan?

2. Is there any difference in prevailing inclusive education opportunities between rural and urban secondary schools?

\section{Methodology}

The current study was conducted to identify as well as to compare the prevailing inclusive education opportunities between rural and urban secondary schools of Punjab Pakistan. The study was descriptive by nature. According to Creswell (2012) survey provides the most reliable data to evaluate programs and services in academic organizations. Due to such types of experts' opinions, a survey technique was used to collect the data from research participants.

\section{Population}

The target population of the study consisted of secondary school teachers working in male, female, rural, and urban secondary schools of Punjab. Similarly, the handicapped students who had been studying in the male, female, rural, and urban secondary schools of Punjab during the academic session 2012-2015 were also the target population of the study. The accessible population of the study consisted of male, female, secondary school teachers and their secondary level special students from rural and urban schools in conveniently selected five districts viz Okara, Sahiwal, Lahore, Pakpattan, and Kasur.

\section{Sample}

To assure comprehensive representation of the population, the convenient sampling technique was applied to extract the sample of the study. For the selection of the sample five districts, viz Okara, Sahiwal, Lahore, Pakpattan, and Kasur were conveniently chosen. The convenient sampling technique was used because of the visual impairment of the researcher as he could not collect data from far-off districts of Punjab. From all the five districts the researcher randomly selected 20 schools including 10 rural and 10 urban schools. The rural and urban schools were further divided into two strata i.e., 5 male schools and 5 females. From the selected 100 schools secondary level teachers were again randomly selected for the data collection. Thus, the sample of this study comprised 300 teachers. Questionnaires were delivered to all the 300 teachers and 196 teachers returned the filled questionnaires.

\section{Instrument}

The first instrument was a self-reporting questionnaire for secondary school teachers i.e., a Research Questionnaire about the Condition of Available Inclusive Education opportunities in Secondary Schools of Punjab. This questionnaire consisted of 12 items about inclusive education opportunities. The coefficient of reliability (Cronbach Alpha) was calculated for the scale, and it turned out as .882.

The second instrument was a structured interview schedule for the disabled students studying at 
secondary level in inclusive education. There were 17 items in the interview schedule. For the convenience of the students, the interviews were conducted in Urdu and later on translated into English for further analysis.

\section{Data Collection Procedure}

To collect data from the questionnaires were personally administered to the teachers at selected schools. Some educational institutions were in far-flung territories, therefore, from such areas data was obtained with the help of the researcher's friends, class fellows, and colleagues. The second stage of data collection was interviews of disabled students studying in inclusive schools. These interviews were personally carried out by the researcher.

\section{Data Analysis}

Both descriptive and inferential statistics were used to analyze the collected data. The decision about the opportunities for inclusive education was taken based on the mean score of the respondents. Whereas the differences of the opportunities in the rural and urban secondary schools were determined through the application of $t$-test. The interviews were transcribed, coded, and categorized to determine the frequency of coded aspects.

\section{Results/Major Findings}

Table 1: Teachers' Opinions About Admission without Discrimination in their Schools.

\begin{tabular}{llccc}
\hline \multicolumn{1}{c}{ Statement } & Responses & Frequency & Percentage & Mean Score \\
\hline Chance of admission without any & Not Available & 17 & 8.7 & \\
Discrimination & Poor & 21 & 10.8 & \\
& Satisfactory & 36 & 18.5 & 3.54 \\
& Good & 82 & 42.1 & \\
& Excellent & 39 & 20.0 & \\
\hline
\end{tabular}

The above table reveals that a large number of respondents $(42.1 \%)$ reported that the situation about the chance of admission without any discrimination was good in their educational institutions. The mean score ( $\bar{X}=3.54$ ) also expressed the good situation of this opportunity.

Table 2: Teachers' Opinions About the Professional Training for in-service Inclusive Class Teachers.

\begin{tabular}{llccc}
\hline \multicolumn{1}{c}{ Statement } & Responses & Frequency & Percentage & Mean Score \\
\hline Professional pieces of training for in- & Not Available & 12 & 6.2 & \\
service inclusive class teachers & Poor & 20 & 10.3 & \\
& Satisfactory & 27 & 13.8 & 3.70 \\
& Good & 91 & 46.7 & \\
& Excellent & 45 & 23.1 &
\end{tabular}

The above table shows that a big number of respondents $(46.7 \%)$ answered that the condition of special pieces of training for inclusive class teachers was good in their schools. The mean score $(\bar{X}=3.70)$ also narrated the good situation of the opportunity.

Table 3: Teachers' Opinion About the Avoidance of Attitude of Neglection

\begin{tabular}{llccc}
\hline \multicolumn{1}{c}{ Statement } & Responses & Frequency & Percentage & Mean Score \\
\hline Avoid the attitude of neglection with & Not Available & 21 & 10.8 & \\
Special students & Poor & 17 & 8.7 & \\
& Satisfactory & 31 & 15.9 & 3.57 \\
& Good & 82 & 42.1 & \\
& Excellent & 44 & 22.6 & \\
& & & &
\end{tabular}


The above table depicts that a wide range of respondents $(42.1 \%)$ replied that the situation about avoiding attitude of neglection with special students was also good in their educational institutions. The mean score ( $\bar{X}=3.57$ ) supports their answers.

Table 4: Teachers' Opinions About the Participation of Special Students in Academic Activity.

\begin{tabular}{llccc}
\hline \multicolumn{1}{c}{ Statement } & Responses & Frequency & Percentage & Mean Score \\
\hline Participation of special students & Not Available & 28 & 14.4 & \\
In each academic activity & Poor & 24 & 12.3 & \\
& Satisfactory & 23 & 11.8 & \multirow{2}{*}{3.46} \\
& Good & 71 & 36.4 & \\
& Excellent & 49 & 25.1 &
\end{tabular}

The above table shows that a lot of respondents $(36.4 \%)$ were of the opinion that the situation of participation of special students in each academic activity was good in their institutes. The mean score ( $\bar{X}=3.46)$ was supportive of their response as well.

Table 5: Teachers' opinions about the participation of students.

\begin{tabular}{llccc}
\hline \multicolumn{1}{c}{ Statement } & Responses & Frequency & Percentage & Mean Score \\
\hline Participation of students with special & Not Available & 22 & 11.3 & \\
needs in co-curricular activities & Poor & 21 & 10.8 & \\
& Satisfactory & 28 & 14.4 & 3.55 \\
& Good & 76 & 39.0 & \\
& Excellent & 48 & 24.6 & \\
\hline
\end{tabular}

The above table informs that $(39.0 \%)$ respondents opined that the situation about the participation of students with special needs in co-curricular activities was good in their schools. The mean score $(\bar{X}$ $=3.55$ ) represents the good situation of this opportunity.

Table 6: Teachers' opinions about the existence of a collaborative environment among disabled and non-disabled

\begin{tabular}{llccc}
\multicolumn{4}{c}{ students. } & \\
\multicolumn{1}{c}{ Statement } & Responses & Frequency & Percentage & Mean Score \\
\hline Collaborative environment among & Not Available & 22 & 11.3 & \\
disabled and non-disabled students & Poor & 19 & 9.7 & \\
& Satisfactory & 27 & 13.8 & 3.58 \\
& Good & 78 & 40.0 & \\
& Excellent & 49 & 25.1 & \\
& & & & \\
\hline
\end{tabular}

The above table narrates that $(40.0 \%)$ respondents expressed that the situation of collaborative environment among disabled and non-disabled students was good in their educational institutions. The mean score ( $\bar{X}=3.58$ ) was also supporting their opinion.

Table 7: Teachers' opinions about the take care of self-respect of children with special needs.

\begin{tabular}{llccc}
\hline \multicolumn{1}{c}{ Statement } & Responses & Frequency & Percentage & Mean Score \\
\hline Take care of self-respect for special & Not Available & 14 & 7.2 & \\
children & Poor & 10 & 5.1 & \\
& Satisfactory & 21 & 10.8 & 3.94 \\
& Good & 79 & 40.5 & \\
& Excellent & 71 & 36.4 & \\
& & & & \\
\hline
\end{tabular}

The above table explains that (40.5\%) respondents answered that the situation about taking care of selfrespect for special children was good in their schools. The mean score $(\bar{X}=3.94)$ also expressed same 
reality.

\section{Discussion on Major Findings}

This study aimed at identifying the available inclusive education opportunities in the secondary schools of Punjab Pakistan. At the same time, the comparison of existing inclusive education opportunities between rural and urban secondary schools of Punjab was also an objective of the study. The study narrated that the situation of inclusive education opportunities was good in the urban as well as the rural secondary schools of Punjab. It is a proven fact that there is a severe lack of physical and infrastructural facilities of inclusive education in general schools of South Asia. Simultaneously different researchers report that despite many gaps, there is a hopeful situation regarding inclusive education opportunities and desired attitudes in mainstream schools of this region. Julia and Bansal (2013) support the findings of this study that there are a lot of well-organized funded programmers like the IEDSS which provide full provision to facilitate inclusive education at the secondary and higher secondary stage (Julka \& Bansal, 2013).

On the other hand, Kohama (2012) contradicts the findings of this study in the case of sufficient training opportunities for inclusive education teachers that instructors and school heads have no professional development for inclusive education, and it badly influences the students' achievements. Finally, Farooq bears out the results of the study at hand that although the general education schools are not obligated to accommodate the students with special needs. However, they give their generous support to them. In spite of the lack of proper professional development opportunities and behavioral modification, teachers at mainstream schools welcome the disabled children in their classes, as well as the non-disabled peers of special students, and behave in an encouraging way to them (Farooq, 2012).

\section{Conclusions}

In spite of the lack of inclusive education facilities, it is an amazing fact that there is a good condition of inclusive education opportunities and desired attitudes in the secondary schools of Punjab. There is a good chance of admission without any discrimination, collaborative environment between disabled and non-disabled students, caretake of self-respect for special children, good condition of avoidance of neglective attitude with special students, and avoidance of overprotective attitude with disabled students. There is a good situation of participation of special students in each academic activity, participation of students with special needs in co-curricular activities, similarly there exists evidence of assigning the seats to special students according to their special needs.

The secondary schools of Punjab have good financial encouragement and support for both inclusive class teachers and special students. The study shows that there are special incentives for inclusive class teachers, good conditions of scholarship for brilliant disabled students, financial aid for needy handicapped students. Similarly, there is an opportunity for special trainings for inclusive class teachers. The present study describes that there is no significant difference in inclusive education opportunities between rural and urban secondary schools of Punjab.

The admission policy of secondary schools is accommodating for children with special needs. Particularly for those students who have minor disabilities. The secondary schools of Punjab do not have need-based and merit-based scholarships, satisfactory instructional and examinational methodology, as well as services and strategies to fulfill the special educational needs of students with impairments.

In most of the schools, teachers, school staff and examination staff show non-cooperative attitudes towards disabled students. There is no equal chance of participation in curricular and co-curricular activities for CWSN. In spite of these realities, it is a sign of hope that peers and classmates of handicapped students support their special fellows in their capacity. 


\section{Recommendations/Implications of the study}

The following recommendations are presented based on the results of study:

$>$ Although teachers at secondary schools reported a good situation about ensuring the self-respect of persons with disabilities, in fact, students with special needs fully denied their claim and expressed the non-cooperation of teachers and staff. So, the situation needs to be improved and their level of trust should be raised.

$>$ Special students may be encouraged for taking part in the curricular as well as in co-curricular activities because special students are found dissatisfied and disappointed.

$>$ The provision of merit-based and need-based scholarships may also be enhanced and regularized.

$>$ Comprehensive and fruitful Programs for professional development of inclusive class teachers and examination staff regarding inclusive education should be arranged.

\section{References}

Booth, T. (1996). A Perspective on Inclusion from England. Cambridge Journal of Education, 87-99.

Booth, T., Ainscow, M., \& Dyson, A. (1997). Understanding inclusion and exclusion in the English competitive education system. International journal of inclusive education, 1(4), 337-355.

Biamba, C. (2016). Inclusion and Classroom Practices in a Swedish School: A Case Study of a School in Stockholm. Journal of Education and Practice, 7(3), 119-124.

Creswell, J. W. (2012). Educational Research Planning, Conducting, and Evaluating Quantitative and Qualitative Research. Boston: Pearson Education.

Imhoff, S. (2017). Why disability studies need to take religion seriously. Religions, 8(9), 186.

Jahanzaib, M., Fatima, G., \& e Nayab, D. (2019). Inclusive Education Facilities in Secondary Schools of

Pakistan: A Gender Based Comparison. Responsible Education, Learning and Teaching in

Emerging Economies, 1(2), 75-83.

Khan, A. H., \& Shahnaz, L. (2000). Determinants of Internal Migration in Pakistan. The Pakistan Development Review , 695-712.

Leo, K. (1964). A HISTORY OF THE CARE AND STUDY OF THE MENTALLY RETARDED. Education resources information centre (ERIC), 1.

Otieno, P. A. (2009). Biblical perspectives on disability and emerging theological themes. Disability studies quarterly the first journal in the field of disability studies volume 29 no. 4 .

Otieno, P. A. (2009). Biblical and theological perspectives on disability: Implications on the rights of persons with disability in Kenya. Disability Studies Quarterly, 29(4).

Rymer, E. (2014). Children of ancient greece. Retrieved 11 16, 2014, from Make your words echo into the future.

Tremblay, P., \&Tivat, M. (2007). Special needs education basis: Historical and conceptual approach. UniversiteLibre de Bruxelles.

UNESCO. (2005). Guidelines for inclusion. paris: unesco.

UNESCO. (1994). The millennium development goals: They are about children. UNESCO

Winzer, M. A. (1993). The history of special education: From isolation to integration. Gallaudet University Press.

Waldschmidt, A., Meinert, S., (2010): ANED country report on equality of educational and training opportunities for young disabled people: Germany, ANED, University of Leeds. 